\title{
Adverse reactions following mass drug administration with diethylcarbamazine in lymphatic filariasis endemic areas in the Northeast of Brazil
}

\author{
Ana Wládia Lima ${ }^{[1]}$, Zulma Medeiros ${ }^{[2]}$, Zailde Carvalho dos Santos ${ }^{[1]}$, \\ Gertrudes Monteiro da Costa ${ }^{[3]}$ and Cynthia Braga ${ }^{[2]}$
}

[1]. Centro Acadêmico de Vitória, Universidade Federal de Pernambuco, Vitória de Santo Antão, PE. [2]. Centro de Pesquisas Aggeu Magalhães, Fundação Oswaldo Cruz, Recife, PE. [3]. Secretaria de Saúde do Recife, Distrito Sanitário II, Recife, PE.

\begin{abstract}
Introduction: The Global Programme to Eliminate Lymphatic Filariasis was launched with the goal of eliminating this disease via the annual mass drug administration (MDA) of a single dose of antifilarial drugs. Adverse drug reactions following MDA are a major factor of poor treatment adherence in several countries. This study assessed the occurrence of adverse drug reactions (ADRs) following the first round of mass treatment in two communities treated with different dosages of diethylcarbamazine (DEC) in the City of Recife, Brazil. Methods: Population-based cross-sectional surveys were conducted in a random sample of the population living in both communities (Areas I and II). The dose of DEC recommended by the WHO $(6 \mathrm{mg} / \mathrm{kg})$ was calculated based on the individual's weight-for-age. In Area II, weight differences between the genders were also considered when determining dosage. Data were obtained through interviews conducted in the first 12 to $48 \mathrm{~h}$ and on the $5^{\text {th }}$ day after MDA during household visits. Results: A total of 487 and 365 individuals were interviewed in Areas I and II, respectively. The prevalence of ADRs in Area I (23.6; 95\% Cl: 19.1-29.5) was higher than in Area II (16.2; 95\%Cl:11.9-21.5)( $\mathrm{p}=0.0078)$. The prevalence of ADRs among females was higher than in males in Area I $(p=0.0021)$. In Area II, no significant difference between the genders was observed $(p=0.1840)$. Age was not associated with ADRs in either area. Conclusions: Adjusting MDA dosage schedules according to weight-for-age and sex may be may contribute to reduce the occurrence of adverse drug reactions in the population.
\end{abstract}

Keywords: Lymphatic filariasis. MDA program. Adverse drug reactions. Prevalence study.

\section{INTRODUCTION}

Since the launch of the Global Programme to Eliminate Lymphatic Filariasis (GPELF) by the World Health Organization (WHO) in 1997', mass drug administration (MDA) programs have been conducted in a large number of endemic countries. By 2009, 385 million people had been treated, and two billion doses of antifilarial drugs had been distributed in 53 endemic countries ${ }^{2,3}$. It is estimated that these actions resulted in approximately 32 million disability-adjusted life years averted and protected 6.6 million neonates from clinical disease ${ }^{3}$.

Low treatment-coverage rates in MDAs (<70\%) place the success of elimination programs at risk ${ }^{4}$ and have been linked to failures in drug distribution, lack of perceived treatment benefit by the population and fear of adverse reactions ${ }^{5-7}$.

Due to the potent microfilaricidal effect of diethylcarbamazine citrate (DEC) on Wuchereria bancrofti, with or without other drugs (Albendazole or Ivermectin), it has been the drug of choice in most lymphatic filariasis (LF) mass treatment programs in areas without co-endemic onchocerciasis ${ }^{4,8,9}$. Despite good tolerability, the drug can produce adverse reactions such as drowsiness, nausea, fever, headache, arthralgia, lymphangitis, lymphadenitis, orchitis, epididymitis and other symptoms. These reactions are associated

\footnotetext{
Address to: Drạ Ana Wládia Silva de Lima. Centro Acadêmico da Vitória/UFPE. Alto do Reservatório s/n, 55608-680 Vitória de Santo Antão, PE, Brasil.

Phone: 5581 3523-0670

e-mail: anwladia@bol.com.br

Received in 14/02/2012

Accepted in 23/10/2012
}

with the dose-related chemical toxicity of the drug or, occasionally, with the death of the parasite ${ }^{10}$.

Adverse drug reactions (ADRs) in MDA programs have been a major factor related to poor treatment adherence in several countries ${ }^{5,6,11,12}$. Variations in the occurrence of adverse reactions across MDA programs using different treatment schemes have been observed among people of different ages ${ }^{13}$, sexes $^{13,14}$ and microfilaraemia statuses ${ }^{14}$.

The Metropolitan region of the State of Pernambuco in northeastern Brazil is the remaining focus of lymphatic filariasis in Brazil| ${ }^{15,16-18}$, and MDAs with annual single doses of DEC only $(\approx 6 \mathrm{mg} / \mathrm{kg})$ have been implemented since $2003^{17}$. According to a parasitological survey conducted between 1999 and 2000 ( $n=18,279)$ in the City of Recife, the capital of the state, two neighborhoods (Agua Fria and Alto Santa Terezinha) reached the highest levels of endemicity in the city, with a prevalence of $6.2 \%$ and $10.4 \%$, respectively (Health Department of Recife, unpublished data). Initially, two areas in these neighborhoods were selected for MDA with distinct dosages of DEC. This article reports the occurrence of adverse drug reactions following the first round of MDA in these areas.

\section{METHODS}

\section{Study design and settings}

Recife has an area of $217.5 \mathrm{~km}^{2}$ and a population of 1,536,934 inhabitants (IBGE, 2010). MDA in this city, with annual single doses of DEC, started in 2003, and nearly 150,000 people were treated by $2009^{19}$.

The population-based cross-sectional survey was conducted in a random sample of the population eligible for MDA in both areas. Area I is located at the intersection between the neighborhoods of 
Agua Fria and Alto Santa Terezinha. It had a population of 20,891 inhabitants at the time of the survey, and the first round of MDA was conducted in November of 2003. Area II is in the neighborhood of Alto Santa Terezinha (Area II). It had a population of 3,332 inhabitants, and the first round of MDA was conducted in November 2004 (Figure 1). A pre-MDA parasitological survey conducted in a random population sample of the areas found a prevalence of microfilaraemia of $5.5 \%$ and an average microfilaraemic density of $55.1 \mathrm{mf} / \mathrm{mL}$ (ZC Santos: personal communication, 2006 ).

The populations were comprised primarily of young people ( $25 \%$ were children under 15 years). Approximately $16 \%$ of the population was illiterate or had less than one year of schooling, and the average family monthly income was 206.00 USD (United States dollars) ${ }^{20}$.

\section{MDA treatment schemes}

Residents aged from four years, excluding pregnant women and individuals with severe heart, renal or liver disease, were eligible for treatment. All the residents were registered and treated in treatment units specifically organised for that purpose and distributed at strategic points in the communities. The residents who did not attend these units were treated in their own residence.
The dose of DEC was determined based on the dosage guideline of $6 \mathrm{mg} / \mathrm{kg}$, as recommended by the $\mathrm{WHO}^{21}$. Table 1 shows the average weight for the $25^{\text {th }}$ percentile of the National Center for Health Statistics (NCHS) growth curve ${ }^{22}$ and the dosage of DEC for each age group. In area I, the dosages were calculated based on the average weight-for-age of each age group. In Area II, the dosages were calculated using the same parameter while also considering differences in weight between the sexes.

\section{Sample size calculation and sampling strategy}

The sample size was calculated assuming a prevalence of adverse effects of $10 \%{ }^{23}$, a standard error of $3 \%$, a $95 \%$ confidence interval and design effect of 1.5 (to take into account the variation of positives in each household). This yielded a sample of 450 individuals in each area.

The areas were mapped. Households were counted, and resident registration was conducted. A systematic sample of the households in each area was then drawn based on the calculation of a sampling fraction that was determined considering the mean number of people eligible for MDA per household. All the persons who underwent MDA treatment in the selected households participated in the survey.

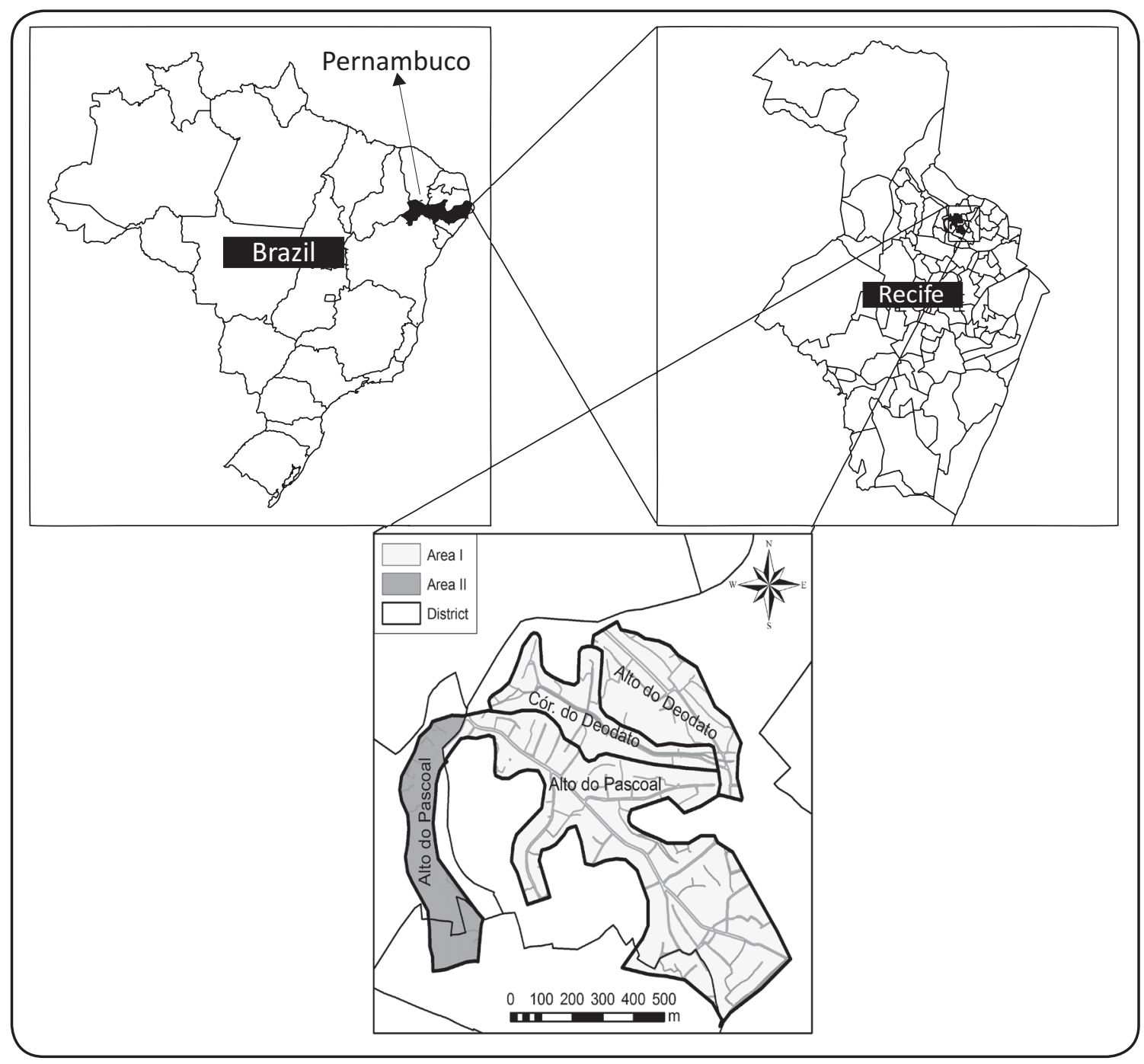

FIGURE 1 - Map of the Recife, State of Pernambuco, Brazil, with emphasis on the two areas of study- Area I (Água Fria) and Area II (Alto Santa Terezinha). 
TABLE 1 - Estimated weight (NCHS curves), dosage schedules and average dose ( $\mathrm{mg} / \mathrm{kg}$ ) of diethylcarbamazine citrate by age group and sex in mass treatment of the Areas I and II. Recife, Brazil, 2003-2004.

\begin{tabular}{|c|c|c|c|c|c|c|c|c|c|}
\hline \multirow[b]{4}{*}{ Age group (years) } & & & \multicolumn{3}{|c|}{ Area I } & \multicolumn{4}{|c|}{ Area II } \\
\hline & & & \multirow{3}{*}{$\begin{array}{c}\text { DEC } \\
\text { doses }(\mathrm{mg})^{* *}\end{array}$} & \multirow{2}{*}{\multicolumn{2}{|c|}{$\begin{array}{c}\text { average dose } \\
\text { of DEC }(\mathrm{mg} / \mathrm{kg})\end{array}$}} & \multicolumn{2}{|c|}{ male } & \multicolumn{2}{|c|}{ female } \\
\hline & \multicolumn{2}{|c|}{ Average weight $(\mathrm{kg})^{*}$} & & & & \multirow{2}{*}{$\begin{array}{c}\text { DEC } \\
\text { doses }(\mathrm{mg})^{* *}\end{array}$} & \multirow{2}{*}{$\begin{array}{c}\text { average dose } \\
\text { of DEC ( } \mathrm{mg} / \mathrm{kg})\end{array}$} & \multirow{2}{*}{$\begin{array}{c}\text { DEC } \\
\text { doses (mg) }\end{array}$} & \multirow{2}{*}{$\begin{array}{l}\text { average dose } \\
\text { of DEC }(\mathrm{mg} / \mathrm{kg})\end{array}$} \\
\hline & male & female & & male & female & & & & \\
\hline $4-8$ & 17 & 17 & 100 & 5.9 & 5.9 & 100 & 5.9 & 100 & 5.8 \\
\hline $7-10$ & 25 & 23 & 150 & 6.0 & 6.3 & 150 & 6.0 & 150 & 6.3 \\
\hline $11-14$ & 38 & 38 & 200 & 5.3 & 5.3 & 200 & 5.3 & 200 & 5.2 \\
\hline $15-17$ & 55 & 48 & 250 & 4.5 & 5.2 & 250 & 4.5 & 200 & 4.2 \\
\hline$>18$ & 60 & 50 & 300 & 5.5 & 6.0 & 300 & 5.5 & 250 & 5.0 \\
\hline
\end{tabular}

DEC: diethylcarbamazine; NCHS: National Center for Health Statistics; DEC: diethylcarbamazine. ${ }^{*} 25^{\text {th }}$ percentile of the NCHS curve for for the average age of each age group; ${ }^{*} 50 \mathrm{mg}$ tablets.

\section{Data collection and variables}

Data collection in Areas I and II was performed in November 2003 and September 2004, respectively.

Demographic data (age, sex) and information on the occurrence of adverse reactions were obtained through interviews conducted directly with the participants or their guardians (if the participant was $<13$ years of age) during home visits in the first 12 to $48 \mathrm{~h}$ after treatment. The interviews were conducted by trained nursing graduate students and nurses using a standardised and pre-tested questionnaire.

ADRs were defined as the self-report of local manifestations (swelling/pain of the scrotum or genitals, lymphedema of the lower or upper limb, abscess or lymphangitis) or systemic symptoms (fever, sweating, asthenia, drowsiness, dizziness, lethargy, headache, nausea, vomit, abdominal discomfort or pain or urticaria).

\section{Data analysis}

The prevalence of ADRs and their respective 95\% confidence intervals $(95 \% \mathrm{Cl})$ were estimated in each area according to sex and age group. The frequency distribution of adverse reactions was described according to type (local and systemic). The association between the prevalence of adverse effects and area, sex and age group was tested by calculating the prevalence ratio (PR) and prevalence difference (PD), $95 \% \mathrm{Cl}$ and $\mathrm{p}$-value $(\leq 0.05)$.

\section{Ethical considerations}

The study was reviewed and approved by the Ethics Committee of the Centro de Pesquisas Aggeu Magalhães (CAAE: 0780.0.095.000-05). The participants were interviewed after reading and signing an informed consent form. Cases of adverse reactions were addressed at the local health units and referred to medium or high complexity health services when necessary.

\section{RESULTS}

In Area I, a total of 487 individuals were treated in the selected households ( $n=152$ ) and $438(90 \%)$ were asked about the occurrence of ADRs. Of these, 207 (47.3\%) were male, and 231 (52.7\%) were female. In area II, all 365 people treated in the selected households $(n=85)$ were interviewed. This included 168 (46\%) males and 197 (54\%) females. Table 2 shows the eligible and treated populations, the study sample and the overall prevalence of ADRs in both areas. The prevalence of ADRs in Area I was higher than in Area II (PD=7.6\%; 95\% Cl: 2.1\%-14.0\%; $p=0.0078$ ).

The prevalence of ADRs among females was almost two times higher than that observed in males in Area I; this difference was statistically significant $(\chi 2=9.43 ; p=0.0021)$. Although the prevalence of ADRs was higher among females in Area II, the difference was not statistically significant $(\chi 2=1.76 ; p=0.1840)$. Age was not statistically associated with ADRs in either area (Table 3).

TABLE 2 - Eligible and treated population, study sample and reported cases of adverse drug reactions following mass treatment with diethylcabamazine in the two selected areas. Recife, Brazil, 2003-2004.

\begin{tabular}{lcc}
\hline Characteristics & Area I & Area II \\
\hline Eligible population & 20,891 & 3,332 \\
Population treated (\%) & $18,491(88.5)$ & $2,391(71.6)$ \\
Study sample & 438 & 356 \\
Reported cases of ADRs & 104 & 59 \\
Prevalence of ADRs (95\% Cl) & $23.6(19.1-29.5)$ & $16.2(11.9-21.5)$
\end{tabular}

ADRs: adverse drug reactions; $95 \% \mathrm{Cl}$ : $95 \%$ confidence interval.

TABLE 3 - Frequency distribution and prevalence ratio of adverse drug reactions reported cases following the first dose of mass treatment for bancroftian filariasis according to sex and age groups in the Areas I and II. Recife, Brazil, 2003-2004.

\begin{tabular}{|c|c|c|c|c|c|c|c|c|}
\hline \multirow[b]{2}{*}{ Characteristics } & \multicolumn{4}{|c|}{ Area I } & \multicolumn{4}{|c|}{ Area II } \\
\hline & $\begin{array}{c}\text { population } \\
\text { sample }\end{array}$ & $\begin{array}{l}\text { adverse drug } \\
\text { reactions (\%) }\end{array}$ & $\begin{array}{l}\text { prevalence ratio } \\
\qquad(95 \% \mathrm{Cl})\end{array}$ & $\begin{array}{c}P \\
\text { value }\end{array}$ & $\begin{array}{c}\text { population } \\
\text { sample }\end{array}$ & $\begin{array}{l}\text { adverse drug } \\
\text { reactions (\%) }\end{array}$ & $\begin{array}{l}\text { prevalence ratio } \\
\qquad(95 \% \mathrm{Cl})\end{array}$ & $\begin{array}{c}p \\
\text { value }\end{array}$ \\
\hline \multicolumn{9}{|l|}{ Sex } \\
\hline male & 207 & 35 (16.9) & 1.00 & 0.0021 & 168 & $22(13.1)$ & 1.00 & 0.1840 \\
\hline female & 231 & 69 (29.9) & $1.77(1.23-2.53)$ & & 197 & $37(18.8)$ & $1.43(0.88-2.83)$ & \\
\hline \multicolumn{9}{|c|}{ Age group (years) } \\
\hline$\leq 14$ & 119 & $25(21.0)$ & 1.00 & 0.7283 & 111 & $13(11.7)$ & 1.00 & 0.4760 \\
\hline $15-44$ & 232 & $56(24.2)$ & $0.87(0.57-1.31)$ & & 191 & $34(17.8)$ & $0.66(0.36-1.19)$ & \\
\hline$\geq 45$ & 22 & $22(25.3)$ & $0.83(0.50-1.37)$ & & 63 & $12(19.0)$ & $0.61(0.30-1.26)$ & \\
\hline
\end{tabular}

Cl: $95 \%$ confidence interval. 
More than $90 \%$ of the symptoms reported by both sexes in the two areas were classified as systemic reactions (Table 4). The number of symptoms reported in Area I was 2 times greater than that reported in the Area II.

In Area I, the most commons ADRs were drowsiness, nausea, headache and dizziness. In Area II, drowsiness, nausea and stomach discomfort/pain were the most commonly reported symptoms. Reports of local reactions comprised less than $3 \%$ of the signs and symptoms in both areas. Reported local symptoms included 3 cases of scrotal reaction, 2 cases of lymphangitis and 1 case of lymphedema (Table 4).

\section{DISCUSSION}

Annual mass treatment with antifilarial drugs of populations at risk is one of the main strategies used to achieve the goal of the global elimination of lymphatic filariasis. High MDA compliance rates for more than one round of treatment is an essential requirement of interrupting transmission ${ }^{24}$ and has been one of the challenges of elimination programs underway around the world $d^{7,11,25}$. The fear of adverse reactions by the population has been a major reason for noncompliance in lymphatic filariasis elimination programs $s^{5-7}$. Therefore, new strategies aimed at reducing the adverse effects on treatment programs may contribute to maintaining MDA compliance rates at acceptable levels ( $280 \%$ ) in LF elimination programs ${ }^{2}$.

This study describes the occurrence of adverse reactions following MDA in two contiguous endemic areas with similar socioeconomic characteristics and endemicity levels submitted to distinct DEC treatment schemes. The prevalence rates of ADRs in the two areas of approximately $20 \%$ were similar to those described in active surveillance reports of ADRs following the use of DEC alone or in combination with other antifilarial drugs in several endemic Areas ${ }^{14,26}$.

The overall prevalence of ADRs in Area I, where the dosage of DEC was calculated with respect to the differences in weight according to age only, was significantly higher than that observed in Area II, where weight differences between the sexes were also considered. It was also observed that the prevalence of ADRs was significantly higher among females than males in area I. While the prevalence of ADRs among women was greater than in men in Area II, this difference was not statistically significant. Moreover, most of the reported adverse reactions in both areas were classified as systemic and mainly reported by the women. Common symptoms included drowsiness, nausea, headache, dizziness and abdominal pain. These manifestations are particularly related to the chemical toxicity of the drug and the death of microfilariae ${ }^{27,28}$. Considering the geographical proximity of the areas, the similarities in their socioeconomic characteristics, their comparable endemic levels and the surveillance methods adopted, it is reasonable to assume that the lower prevalence of ADRs found in Area II could be attributed to the lower DEC dosage administered to women in area II. This assumption is reinforced by the fact that a two-fold higher number of signs and symptoms were reported by the women from Area I than in Area II.

Data on the frequency distribution of ADRs reported by sex following MDA with DEC alone or in combination with albendazole have been inconsistent ${ }^{13,25,29}$. Our results are in accordance with those reported in Sri Lanka where a significantly higher frequency of ADRs was found among females compared to males (54\% versus $46 \%)^{25}$. On the other hand, a higher incidence of ADRs was reported among males in Haiti $^{13}$, and a lack of association between ADRs and sex was reported in India ${ }^{14,30}$.

No variation in the occurrence of ADRs between age groups was observed in the study areas. This result is different from the results of surveys conducted in other endemic areas where an increased frequency of ADRs with age was reported ${ }^{13,14,25}$. Based on these findings, we conclude that variations in the occurrence of ADRs among sex and age groups mainly occur due to differences in the surveillance methods applied, the distinct drug treatment dosages and regimes and local variations in the epidemiological patterns of the disease.

The occurrence of an information bias due to both the interviewer and the surveyed individual having knowledge about the DEC ingestion and the possible ADRs is one possible methodological issue of this study. This problem may have overestimated the prevalence of adverse reactions in both areas; however, the chances of error were similar for the two areas, allowing for a comparative analysis between them. 
Epidemiologic studies in large population samples have shown an increased risk of adverse drug effects among females ${ }^{31,32}$ however, most MDA dosages in LF elimination programs have been defined based on population parameters of weight-for-age $13,14,33,34$ and have not considered sex variations in weight in terms of the tolerability of antifilarial drugs. The data from this study suggest that adjusting dosage schedules in MDA by genders may reduce the occurrence of ADRs, primarily by reducing the number of ADRs in the female population. Based on this result, we conclude that dosage schedules adjusted according to weight-for-age and sex may contribute to reduce the occurrence of adverse drug reactions following MDA. Further studies are needed to assess the impact of these treatment regimens on the incidence of ADRs in other endemic areas.

\section{ACKNOWLEDGMENTS}

The authors would like to thank José Constantino Silveira Junior (CPqAM) for assistance on the map and also the Secretaria Municipal de Saúde of Recife, Distrito Sanitário II, for the administrative support in the field work and entering database.

\section{CONFLICT OF INTEREST}

The authors declare that there is no conflict of interest.

\section{ABSTRACT IN PORTUGUESE}

\section{Reações adversas após tratamento em massa com dietilcarbamazina em áreas endêmicas de filariose linfática no nordeste do Brasil}

Introdução: O Programa Global de Eliminação da Filariose Linfática foi lançado visando à eliminação da doença pela administração de medicamentos em massa (MDA). As reações adversas seguidas ao MDA são um importante fator de baixa adesão ao tratamento em vários países. Este estudo avaliou a ocorrência de reações adversas medicamentosas (ADRs) após a primeira dose de tratamento em massa em duas comunidades tratadas com diferentes doses de dietilcarbamazina (DEC), na Cidade de Recife, Brasil. Métodos: Estudos transversais foram realizados em uma amostra aleatória da população de duas áreas (Áreas I e II). A dose de DEC recomendada pela OMS (6mg/ $/ \mathrm{kg}$ ) foi calculada com base em parâmetros populacionais de peso para a idade. Na Área II, diferenças de peso entre os sexos também foram consideradas no cálculo. Dados foram obtidos através de entrevistas nas primeiras 12 às $48 \mathrm{~h}$ e 50 dia após o tratamento durante visitas domiciliares. Resultados: Um total de 487 e 365 pessoas foi entrevistado nas Áreas I e II, respectivamente. A prevalência de ADRs na Área I (23,6; IC95\%: 19,1-29,5) foi maior do que na Área II (16,2; IC 95\%:11,9-21,5)( $p=0,0078)$. Na Área I, a prevalência de ADRs foi maior nas mulheres do que nos homens ( $p=0,0021)$, não se observando diferença na Área II $(p=0,1840)$. Idade não esteve associada à ADRs. Conclusões: Doses de tratamento em massa (MDA) ajustadas por peso para a idade e sexo parecem contribuir para redução da ocorrência de ADRs na população.

Palavras-chaves: Filariose linfática. Tratamento em massa. Reações adversas medicamentosas. Estudo de prevalência.

\section{REFERENCES}

1. Freitas H, Vieira JB, Braun R, Medeiros Z, Rocha EMM, Santos AAR, et al. Workshop para avaliação da situação epidemiológica da filariose linfática no Município de Belém, Pará, norte do Brasil. Rev Soc Bras Med Trop 2008; 41:212-216.

2. World Health Organization (WHO). Lymphatic Filariasis elimination. WHO; 2011.
3. World Health Organization. Global programme to eliminate lymphatic filariasis. Wkly Epidemiol Rec 2010; 85:365-372.

4. Ottesen EA, Duke BO, Karam M, Behbehani K. Strategies and tools for the control/ elimination of lymphatic filariasis. Bull World Health Organ 1997; 75:491-503.

5. Babu BV, Mishra S. Mass drug administration under the programme to eliminate lymphatic filariasis in Orissa, India: a mixed-methods study to identify factors associated with compliance and non-compliance. Trans R Soc Trop Med Hyg 2008; 102:1207-1213.

6. Nujum ZT. Coverage and compliance to mass drug administration for lymphatic filariasis elimination in a district of Kerala, India. International Health 2011; 3:22-26.

7. Cantey PT, Rao G, Rout J, Fox LM. Predictors of compliance with a mass drug administration programme for lymphatic filariasis in Orissa State, India 2008. Trop Med Int Health 2010; 15:224-231.

8. Horton J, Witt C, Ottesen EA, Lazdins JK, Addiss DG, Awadzi K, et al. An analysis of the safety of the single dose, two drug regimens used in programmes to eliminate lymphatic filariasis. Parasitology 2000; 121 (suppl I):147-160.

9. Ottesen EA. Efficacy of diethylcarbamazine in eradicating infection with lymphaticdwelling filariae in humans. Rev Infect Dis 1985; 7:341-356.

10. Dreyer $\mathrm{G}$, Noroes J. Diethylcarbamazine in the treatment of Bancroft's filariasis. Rev Soc Bras Med Trop 1997; 30:229-240.

11. Babu BV, Kar SK. Coverage, compliance and some operational issues of mass drug administration during the programme to eliminate lymphatic filariasis in Orissa, India. Trop Med Int Health 2004; 9:702-709.

12. Babu BV, Nayak AN. Treatment costs and work time loss due to episodic adenolymphangitis in lymphatic filariasis patients in rural communities of Orissa, India. Trop Med Int Health 2003; 8:1102-1109.

13. McLaughlin SI, Radday J, Michel MC, Addiss DG, Beach MJ, Lammie PJ, et al. Frequency, severity, and costs of adverse reactions following mass treatment for lymphatic filariasis using diethylcarbamazine and albendazole in Leogane, Haiti, 2000. Am J Trop Med Hyg 2003; 68:568-573.

14. Babu BV, Rath K, Kerketta AS, Swain BK, Mishra S, Kar SK. Adverse reactions following mass drug administration during the Programme to Eliminate Lymphatic Filariasis in Orissa State, India. Trans R Soc Trop Med Hyg 2006; 100:464-469.

15. Medeiros Z, Gomes J, Beliz F, Coutinho A, Dreyer P, Dreyer G. Screening of army soldiers for Wuchereria bancrofti infection in the metropolitan Recife region, Brazil: implications for epidemiological surveillance. Trop Med Int Health 1999; 4:499-505.

16. Medeiros Z, Bonfim C, Alves A, Oliveira C, Netto MJ, Aguiar-Santos AM. The epidemiological delimitation of lymphatic filariasis in an endemic area of Brazil, 41 years after the first recorded case. Ann Trop Med Parasitol 2008; 102:509-519.

17. Albuquerque MF, Marzochi MC, Sabroza PC, Braga MC, Padilha T, Silva MC, et al. Bancroftian filariasis in two urban areas of Recife, Brazil: pre-control observations on infection and disease. Trans R Soc Trop Med Hyg 1995; 89:373-377.

18. Mattos D, Mota S, Dreyer G. Aspects of the social realities of children and adolescents seen at a reference service for bancroftian filariasis in Recife, state of Pernambuco. Rev Soc Bras Med Trop 2008; 41:29-35.

19. World Health Organization. Global programme to eliminate lymphatic filariasis: progress report on mass drug administration in 2008. Weekly epidemiological record 2009; 42:437-444.

20. Instituto Brasileiro de Geografia e Estatística (IBGE). Censo Demográfico 2000 [Internet]. Características da população e domićílios, resultados do universo da população. Brasilia: IBGE; [cited 2011 May 5]. Available from: www.ibge.gov.br/ home/estatistica/populacao/censo2000/.

21. World Health Organization (WHO). Lymphatic filariasis [Internet]. WHO; 2011 [2011 November 16]. Available from: http://www.who.int/lymphatic_filariasis/disease/en/

22. Kuczmarski RJ, Ogden CL, Grummer-Strawn LM, Flegal KM, Guo SS, Wei R, et al. CDC growth charts: United States: Adv Data; 2000. p. 1-27.

23. Bockarie MJ, Tisch DJ, Kastens W, Alexander ND, Dimber Z, Bockarie F, et al. Mass treatment to eliminate filariasis in Papua New Guinea. N Engl J Med 2002; 347:1841-1848.

24. El-Setouhy M, Abd Elaziz KM, Helmy H, Farid HA, Kamal HA, Ramzy RM, et al. The effect of compliance on the impact of mass drug administration for elimination of lymphatic filariasis in Egypt. Am J Trop Med Hyg 2007; 77:1069-1073. 
25. Gunawardena S, Sri Ranganathan S, Fernandopulle R. Pharmacovigilance through consumer feedback (reporting) in the mass treatment of lymphatic filariasis using diethylcarbamazine and albendazole in two districts of Sri Lanka. Trop Med Int Health 2008; 13:1153-1158.

26. World Health Organization. Report on active surveillance for adverse events following the use of drug co-administrations in the global programme to eliminate lymphatic filariasis. Wkly Epidemiol Rec 2003; 78:315-317.

27. Dreyer G, Pires ML, Andrade LD, Lopes E, Medeiros Z, Tenorio J, et al. Tolerance of diethylcarbamazine by microfilaraemic and amicrofilaraemic individuals in an endemic area of Bancroftian filariasis, Recife, Brazil. Trans R Soc Trop Med Hyg 1994; 88:232-236.

28. Andrade LD, Medeiros Z, Pires ML, Pimentel A, Rocha A, Figueredo-Silva J, et al. Comparative efficacy of three different diethylcarbamazine regimens in lymphatic filariasis. Trans R Soc Trop Med Hyg 1995; 89:319-321.

29. Subramanyam Reddy G, Vengatesvarlou N, Das PK, Vanamail P, Vijayan AP, Kala S, et al. Tolerability and efficacy of single-dose diethyl carbamazine (DEC) or ivermectin in the clearance of Wuchereria bancrofti microfilaraemia in Pondicherry, south India. Trop Med Int Health 2000; 5:779-785.
30. Subramanyam Reddy G, Vengatesvarlou N, Das PK, Vanamail P, Vijayan AP, Kala S, et al. Tolerability and efficacy of single-dose diethyl carbamazine (DEC) or ivermectin in the clearance of Wuchereria bancrofti microfilaraemia in Pondicherry, south India. Trop Med Int Health 2000; 5:779-785.

31. Martin RM, Biswas PN, Freemantle SN, Pearce GL, Mann RD. Age and sex distribution of suspected adverse drug reactions to newly marketed drugs in general practice in England: analysis of 48 cohort studies. Br J Clin Pharmacol 1998; 46:505-511.

32. Rodenburg EM, Stricker BHC, Visser LE. Sex-related differences in hospital admissions attributed to adverse drug reactions in the Netherlands. British J Clin Pharmacol 2010; 71:95-104.

33. Braga C, Dourado I, Ximenes R, Miranda J, Alexander N. Bancroftian filariasis in an endemic area of Brazil: differences between genders during puberty. Rev Soc Bras Med Trop 2005; 38:224-228.

34. Pani SP, Das LK, Vanamail P. Tolerability and efficacy of a three-age class dosage schedule of diethylcarbamazine citrate (DEC) in the treatment of microfilaria carriers of Wuchereria bancrofti and its implications in mass drug administration (MDA) strategy for elimination of lymphatic filariasis (LF). J Commun Dis 2005; 37:12-17. 